\title{
NATIONAL LIBRARY WITH FUTURISTIC ARCHITECTURE APPROACH IN EAST KALIMANTAN PERPUSTAKAAN NASIONAL DENGAN PENDEKATAN ARSITEKTUR FUTURISTIK DI KALIMANTAN TIMUR
}

\author{
Tri Indaj Krismoniawati ${ }^{1)}$, Mutiawati Mandaka ${ }^{2)}$, Carina Sarasati) \\ Program Studi Arsitektur, Fakultas Teknik, Universitas Pandanaran \\ triindahk16@gmail.com ${ }^{1)}$ \\ mutia.mandaka@unpand.ac.id ${ }^{2)}$ \\ carinasarasati@unpand.ac.id ${ }^{3)}$
}

\begin{abstract}
Abstrak
Perpustakaan adalah suatu tempat sarana informasi tentang ilmu pengetahuan yang memiliki peranan penting dalam dunia pendidikan yang bertujuan untuk mengubah pola pikir, sudut pandang seseorang baik tentang pentingnya sebuah pendidikan maupun ilmu pengetahuan,keaneragaman budaya Indonesia, dan beberapa informasi skala internasional. Penulis melakukan studi banding dari beberapa perpustakaan internasional seperti : Calgary Central Library, Kanada Austin Central Library, dan AS, Qatar National, Qatar. Pada saat melakukan studi banding, ditemukan beberapa hal penting dalam merancang Perpustakaan Nasional ini seperti : Desain dengan banyak ruang-ruang fleksibel. Masing-masing ruangan di desain dengan fleksible, khusus, dan berorientasi pada komunitas. Pemanfaatan cahaya matahari khususnya pada bagian atrium dengan fasade yang terbuat dari kaca dan yang paling utama adalah ketersediaan tempat koleksi buku yang melimpah, Perpustakaan Nasional juga buka hanya sekedar tempat penyimpanan buku, namu juga ekshibisi.
\end{abstract}

Kata Kunci : Perpustakaan Nasional, dengan Desain Fleksibel,berorientasi komunitas,koleksi buku, Arsitektur Fututuristik.

\begin{abstract}
The library is a place for information about science that has an important role in the world of education which aims to change the mindset, a person's point of view about the importance of education and science, the diversity of Indonesian culture, and some information on an international scale. The author conducted a comparative study of several international libraries such as: Calgary Central Library, Canada Austin Central Library, and the US, Qatar National, Qatar. During the comparative study, several important things were found in designing this National Library, such as: Design with lots of flexible spaces. Each room is designed to be flexible, special, and community-oriented. Utilization of sunlight, especially in the atrium with a facade made of glass and the most important thing is the availability of an abundant
\end{abstract}


collection of books, the National Library is also not just a place to store books, but also an exhibition.

Keywords: National Library, with Flexible Design, community oriented, book collection, Futturistic Architecture.

\section{PENDAHULUAN}

Kalimantan Timur atau biasa disebut Kaltim adalah sebuah provinsi di Indonesia di Pulau Kalimantan bagian ujung timur yang berbatasan dengan Malaysia, Kalimantan Utara, Kalimantan Tengah, Kalimantan Barat. Luas total Kaltim adalah 129.066,64 $\mathrm{km}^{2}$ dan populasi sebesar 3.6 juta. Kaltim merupakan wilayah dengan kepadatan penduduk terendah keempat di nusantara. Ibukotanya adalah Samarinda.

Dalam berbagai kamus dan ensiklopedia pemabca dapat menemukan definsi perpustakaan nasional misalnya pada International Encyclopedia of Information and Library Science (1997). Definisi yang diberikannya bermacammacam seperti "Libraries which have a responsibility to collect, maintain and perseve the national litelature" (Ecyclopedia 1997). Harrod memberi batasan sebagai "a library maintained out of government funds and serving the nations as a whole. Ususally books in such libraries are for reference only". Definisi yang diberikan pada terbitan lain umumnya yang hampir sama.

Perpustakaan berkembang pesat dari waktu ke waktu menyesuaikan dengan perkembangan pola kehidupan masyarakat, kebutuhan, pengetahuan, dan teknologi informasi. Perkembangan tersebut juga membawa dampak kepada "pengelompokkan" perpustakaan berdasarkan pola-pola kehidupan, kebutuhan, pengetahuan, dan teknologi informasi tadi. Istilah-istilah perpustakaan "membengkak" menjadi sangat luas namun cenderung mempunyai sebuah spesifikasi tertentu. Dilihat dari perkembangan teknologi informasinya perpustakaan berkembang dari perpustakaan tradisional, semi-tradisional, elektronik, digital hingga perpustakaan "virtual". Kemudian dilihat dari pola kehidupan masyarakat berkembang mulai perpustakaan desa, perpustakaan masjid, perpustakaan pribadi, perpustakaan keliling, dan sebagainya. Kemudian juga dilihat dari perkembangan kebutuhan dan pengetahuan sekarang ini banyak bermunculan istilah perpustakaan umum, perpustakaan khusus, perpustakaan anakanak, perpustakaan sekolah, perpustakaan akademik (perguruan tinggi), perpustakaan perusahaan, dan lain sebagainya.

Mendapatkan landasan konseptual dan perencanaan dan perancangan sebuah bangunan Perpustakaan Nasional untuk memfasilitasi bangunan pemerintah dalam bidang pendidikan dan sebagai wadah masyarakat untuk membaca dan mencari informasi. 
Preseden :

\section{Calgary Central Library, Kanada}

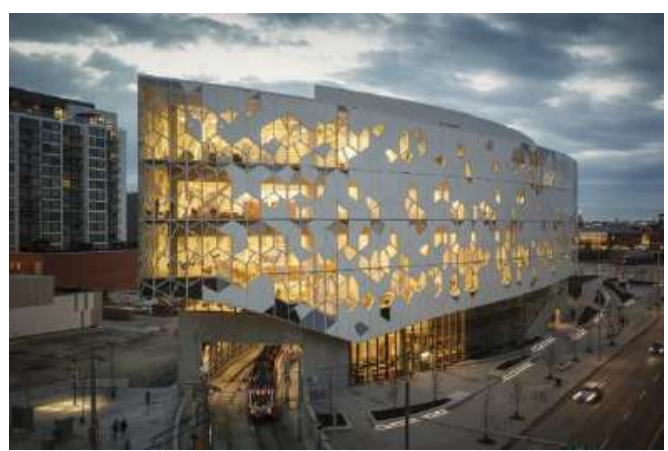

Gambar 1 Fasade

Amfiteater luar ruangan yang terletak di teras menyediakan tempat bagi orang-orang untuk duduk dan progam perpustakaan terbesar di luar penanaman yang mengacu pada lanskap asli menarik pegunungan dan padang rumput Calgary ke dalam lanskap kota, dan berbasis di jalanjalan sekitar alun-alun dengan pohom elm dan aspen. Mengadakan sebagai portal dan jembatan, alun-alun masuk menyembuhkan jahitan yang sebelumnya terbelah antara dua lingkungan dan membangun kembali konveksi visual dan pejalan kaki di seluruh situs.

Geometri Kristal dari façade diukir untuk memperlihatkan gapura kayu yang luas yang merangkul penhunjung saat mereka mendekat. Membingkai pintu masuk gedung, formulis tersebut merujuk pada lengkungan awan Chinooj yang umum ditemukan di wilayah tersebut. Dibuat seluruhnya dari papan kayu cedar merah barat dari dekat Brithish Columbia, cangkang melengkung ganda adalah salah satu cangkang kayu berbentuk bebas terbesar di dunia. Bentuk dan tekstur organiknya membawa bangunan besar itu ke skala sentuhan dan intim. Tampak dari luar gedung adalah atrium utama, mengundang orang masuk.

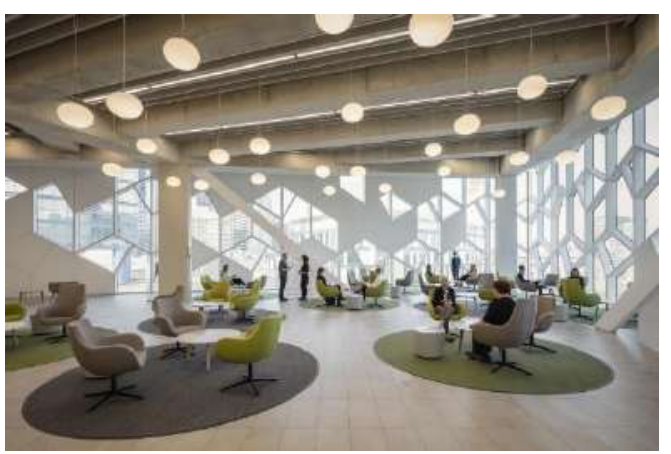

Gambar 2 Interior

Progam perpustakan menempatkan kegiatan public yang lebih hidup di lantai bawah, secara bertahap beralih ke area belajar yang lebih tenang di tingkat atas sebagai satu spiral ke atas. Di permukaan jalan, serangkaian ruangan serba guna berbasis di sekiling bangunan, meningkatkan konektivitas antara bagian dalam dan luar. Di lantai dasar, Perpustakaan Anak-anak menawarkan rumah bermain yang menyediakan ruang untuk kerajinan tangan dan kegiatan berbasis menggambar, progam keaksarasaan awal, dan pengalaman bermain dalam ruangan seluruh tubuh. 


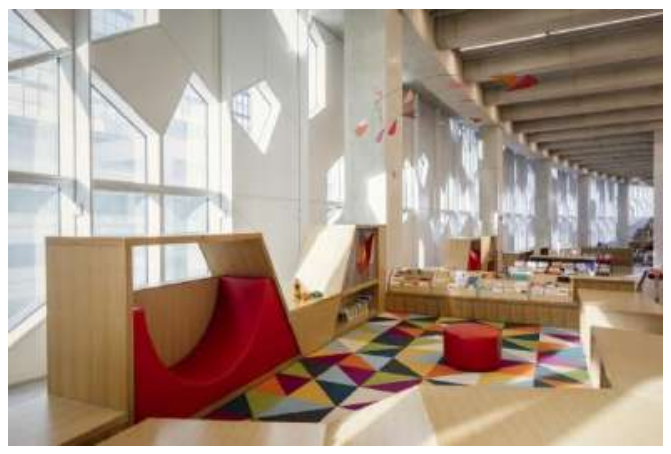

Gambar 3 Interior

\section{Austin Central Library, AS}

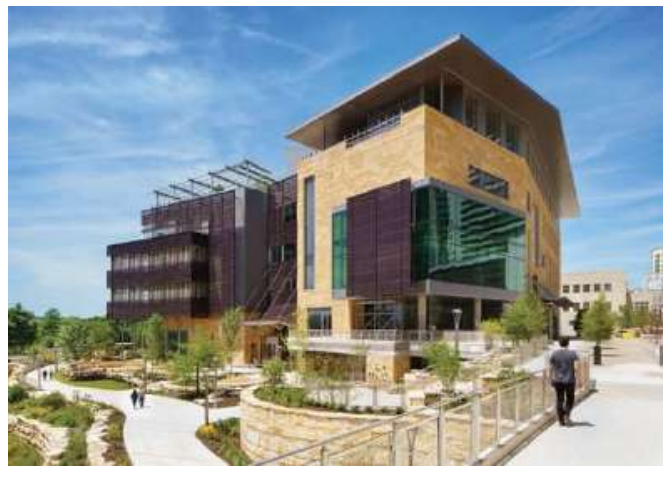

Gambar 4 Fasade

Terdapat lambing sepeda besar di dinding yang menhadap Shoal Creek, yang mendorong pengendara sepeda di jalur sepeda untuk berhenti di perpustakaan yang menyediakan tempat parkir sepeda dan tempat rparasi sepeda. Mendorong pengendara sepeda hanyalah bagian dari kredensial lingkungan gedung perpustakaan ini.

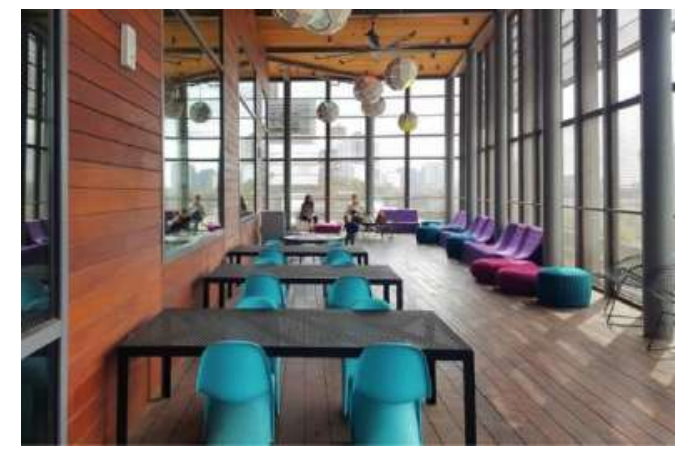

Gambar 5 Interior

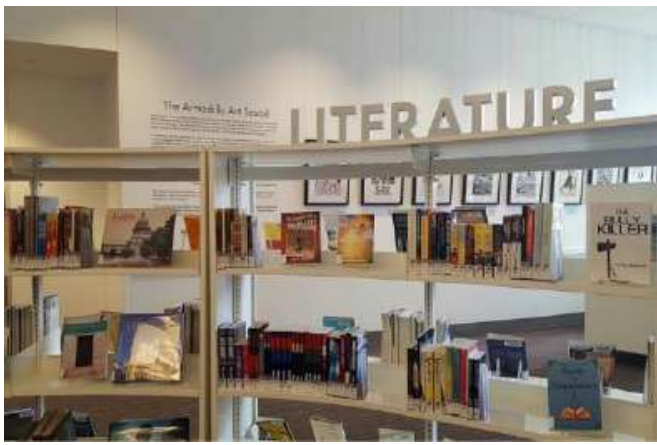

Gambar 6 Interior

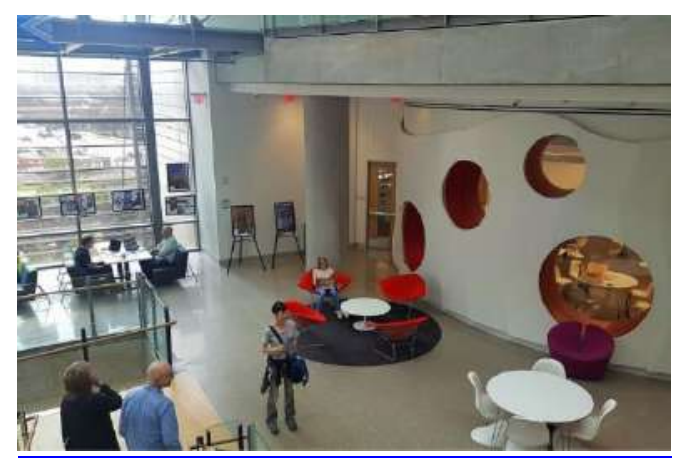

Gambar 7 Interior 


\section{Qatar National, Qatar}

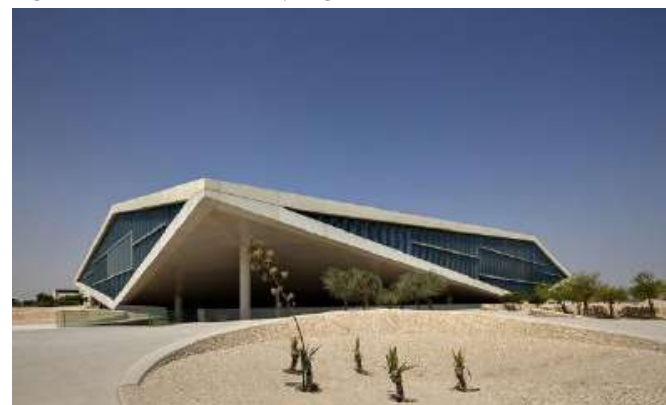

Gambar 8 Fasade
Perpustakaan National Qatar berisi Perpustakaan National Doha, Perpustakaan Umum, dan Perpustakaan Universitas, serta melestarikan koleksi warisan, yang terdiri dari teks dan manuskrio berharga yang terkait dengan peradan Arab-Islam. Perpustakaan umum menampung lebih dari satu juta buku dan ruang bagi ribuan pembaca di atas lahan seluas $42.00 \mathrm{~m} 2$. Perpustakaan merupakan bagian dari Kota Pendidikan, kampus akademik baru yang menampung kampus satelit dari universitas dan institusi termuka dari seluruh dunia.

Perpustakaan Nasional Qatar memainkan peran sentral di Kota Pendidikan, sebuah proyek yang diprakarsai oleh yang Mulia Shiekha Mozah dan Qatar Foundation sebagai bagian dari transisi Qatar ke ekonomi berbasis pengetahuan. Master plan yang di rancang oleh Arata Isozaki pada tahun 1995 dan diresmikan pada tahun 2003 terdiri dari fasilitas pendidikan dan penelitian, termasuk cabang Universitas bertaraf internasional dan markas besar Qatae Foundation, juga dirancang oleh OMA dan selesai pada tahun 2016.

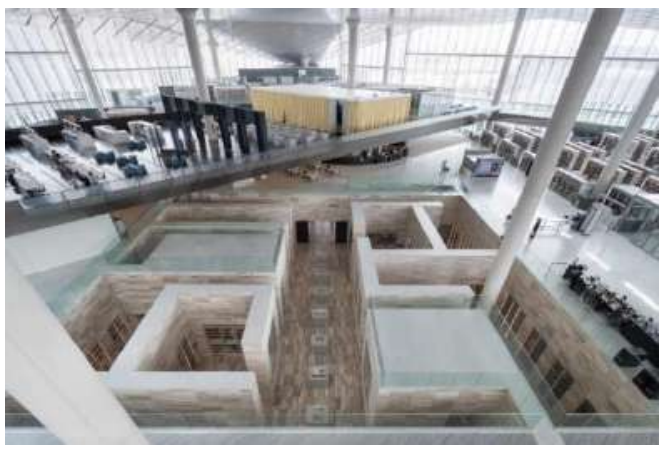

Gambar 9 Interior

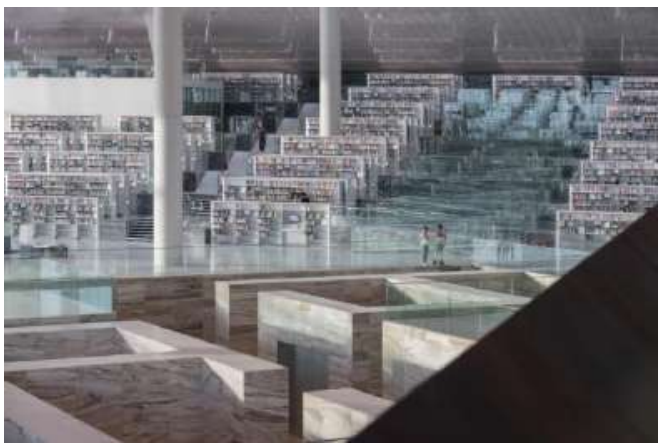

Gambar 10 Interior

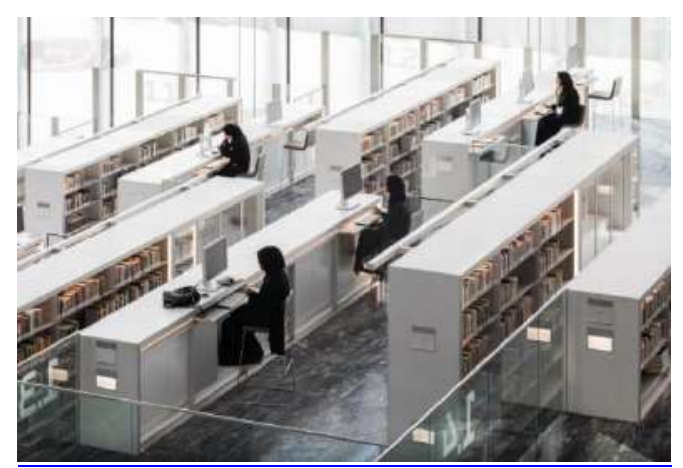

Gambar 11 Interior

Tujuan utama yang ingin dicapai dalam penelitian ini adalah sebagai berikut

1. Bagaimana merancang sebuah perpustakaan nasional di Kalimantan Timur dengan kriteria bangunan dengan pendekatan Arsitektur Futuristik. 
2. Apa saja yang harus diperhatikan dalam perancanga Perpustakaan Nasional.

3. Kapasitas ruang penyimpanan koleksi buku pada Perpustakaan Nasional.

\section{TINJAUAN TEORI}

Futuristik merupakan suatu paham kebebasan dalam mengungkapkan atau mengekspresikan ide atau gagasan ke dalam suatu bentuk tampilan yang tidak biasa, kreatif dan inofatif. Hasil dari futuristic ini adalah sesuatu yang dinamis, selalu berubah-ubah sesuai dengan keinginan zamannya. Penerpan Futuristik ini hanya terlihat pada penampilan tampak nya dengan tetap memperhatikan dan memperhitungkan fungsi dari objeknya (Tiffany, 2012)

Arsitektur futuristik yaitu Arsitektur yang dapat mengikuti dan menampung tuntutan kegiatan yang senantiasa berkembang dan dapat melayani proses pada bangunan tanpa mengganggu bangunan di sekitar dengan jalan perencanaan yang matang. Futuristik sebagai core values atau mengandung niila-nilai yaitu : Dinamis, estetis dan inovatif terutama dari segi teknologi yang dipakai (dinamis, canggih dan ramah lingkungan) dengan mengadopsi bentukbentuk bebas yang tidak terikat oleh bentubentuk tertentu. (Haines, 1950) dan (Chiara,1980)

Pada eskterior depan Bangunan fasade dalam perencanaan Perpustakaan Nasional dengan pendekatan Arsitektur Futuristik akan didominasi oleh penggunaan kaca agar lebih terbuka dengan beberapa penjelasan sebagai berikut :

1. Penggunaan material dominan kaca transparan ini guna mendekati dengan konsep arsitektur futuristic yang dominan material pre frabrikasi seperti kaca.

1. Pemilihan warna cat abu dengan perpaduan putih dimaksud seperti warna plester dan warna dasar yang melambangkan futuristik.

2. Ukuran Fasadde kaca yang berukuran besar dan berbentuk persegi.

3. Penggunaan vegetasi disekitar bangunan guna meredam sinar matahari

5. Perawatan bangunan menjadi mudah

4. Mengurangi biaya pembangunan yang terlalu mahal

\section{METODOLOGI PERANCANGAN}

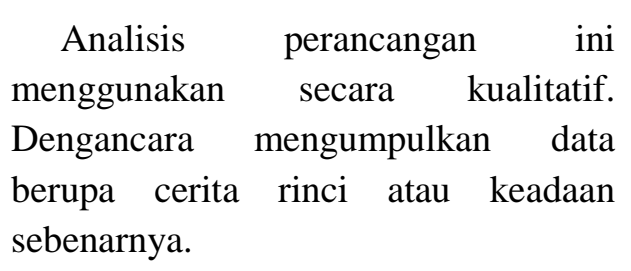

\section{- Pendekatan Aspek Kontekstual}

Pemilihan tapak untuk bangunan Perpustakaan Nasional yang berlokasi di Kalimantan Timur yang berlokasi di Samarinda.

Perpustakaan umum harus terletak pada posisi yang sentral, mudah pencapaianya. Pemilihan lahan harus memperhatikan magnet di lingkungan sekitar lahan berada, seperti pusat kebudayaan, pusat perbelanjaaan, daerah industry, perumahan, dan sebagainya. Secara umum, Persyaratan yang harus diperhatikan dalam pemilihan lahan adalah :
a. Mudah diakases dari jalan utama
b. Terdapat special interest lain yang terletak tidak jauh dari lahan 
c. Akan lebih baik jika lahan tersebut telah diprediksi memiliki potensi untuk dikembangkan.

Berdasarkan kajian literatur yang telah dilakukan terhadap beberapa perpustakaan, dapat disimpulkan kategori letak lahan perpustakaan nasional sebagai berikut :
a. Kompleks pusat kebudayaan
b. Dekat dengan pusat perbelanjaan
c. Daerah Perumahan
d. Dekat dengan Kawasan Pendidikan seperti Kampus
e. Balaikota
f. Museum
g. Di sekitar taman kota

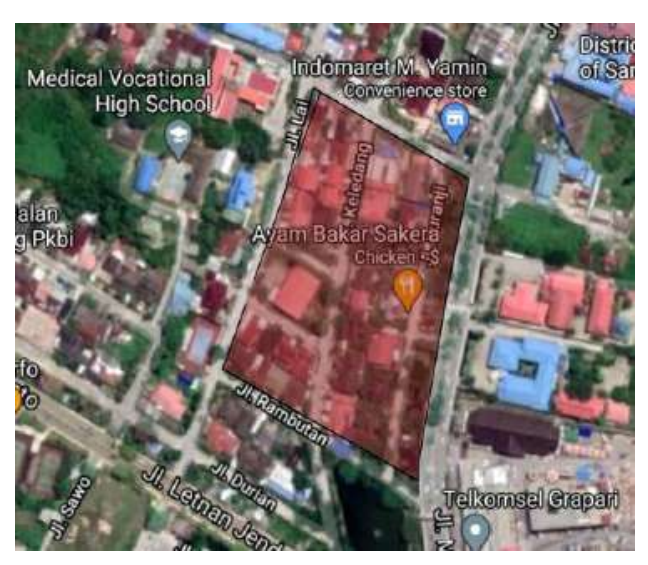

Gambar 12 : Tapak Terpilih

Lokasi tapak berada di J1 Rambutan, Kalimantan Timur dengan luas lahan 2ha. Terdapat jaringan utilitas (lampu penerangan jalan/tiang listrik, air dan jalan selebar 4 meter dengan 2 jalur), Arus lalu lintas ramai, berada di Kawasan Pendidikan, meliputi Universitas, Sekolah menengah Atas, sekolah menengah pertama, Apartemen,Mall dan stadion.

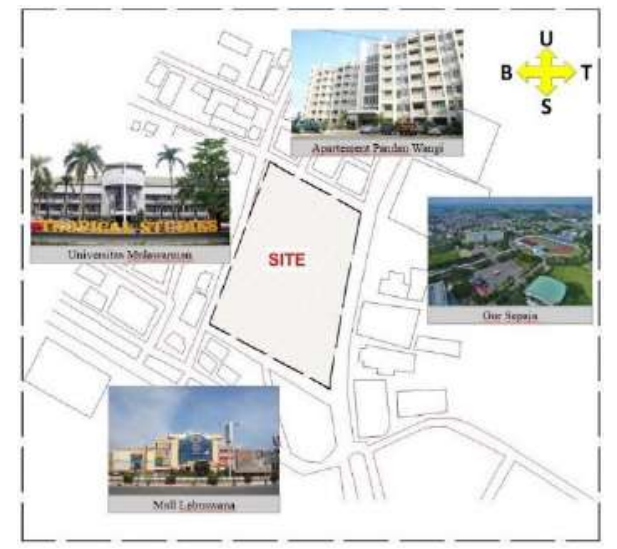

Gambar 13 : View di sekitar Tapak

Jl. Bayangkara Samarinda, Kalimantan Timur dengan luas lahan 29,254 m2. Terdapat jaringan utilitas (lampu penerangan jalan/tiang listrik, air dan jalan selebar 4 meter dengan 2 jalur), Arus lalu lintas ramai, berada di Kawasan Pendidikan, meliputi Universitas, Sekolah menengah Atas, sekolah menengah pertama, Masjid, Kawasan Perumahan, dan Villa.

Timur : IKIP Samarinda

Barat : Universitas Mulawarman

Selatan : Mall Lembuswana

Utara : Apartemen Pandan Wangi Suite Samarinda

- $\quad$ Pendekatan Aspek Fungsional

Tabel 1 : Progam Aktivitas

\begin{tabular}{|l|l|l|l|}
\hline No & Kegiatan & $\begin{array}{l}\text { Kebutuhan } \\
\text { Ruang }\end{array}$ & $\begin{array}{l}\text { Sifat } \\
\text { Ruang }\end{array}$ \\
\hline 1 & Penerima & $\begin{array}{l}\text { Entrance } \\
66,115 \mathrm{~m} 2\end{array}$ & Publik \\
\hline & & $\begin{array}{l}\text { R. } \\
\text { Resepionis } \\
132,23 \mathrm{~m} 2\end{array}$ & Publik \\
\hline & & $\begin{array}{l}\text { Mini Galeri } \\
396,69 \mathrm{~m} 2\end{array}$ & Publik \\
\hline
\end{tabular}




\begin{tabular}{|c|c|c|c|}
\hline \multirow[t]{5}{*}{2} & Perpustakaan & $\begin{array}{l}\text { Ruang Baca } \\
4,628 \mathrm{~m} 2\end{array}$ & Publik \\
\hline & & $\begin{array}{l}\text { Kantor } \\
\text { pengelola } \\
2,47 \mathrm{~m} 2\end{array}$ & $\begin{array}{l}\text { Semi } \\
\text { Publik }\end{array}$ \\
\hline & Galeri & $\begin{array}{l}\text { R. Pameran } \\
991,75 \mathrm{~m} 2\end{array}$ & Publik \\
\hline & Komunikasi & $\begin{array}{l}\text { R. Seminar } \\
528,92 \mathrm{~m} 2\end{array}$ & Publik \\
\hline & & $\begin{array}{l}\text { R. } \\
\text { workshop } \\
859,50 \mathrm{~m} 2\end{array}$ & Publik \\
\hline \multirow[t]{2}{*}{3} & Komersial & $\begin{array}{l}\text { Toko Buku } \\
1,983 \mathrm{~m} 2\end{array}$ & Publik \\
\hline & & $\begin{array}{l}\text { Kafe } \\
1,322 \mathrm{~m} 2\end{array}$ & Publik \\
\hline \multicolumn{4}{|c|}{ Luas Area Terbangun : 13,223 m2 } \\
\hline \multicolumn{4}{|c|}{ Luas Area Terbuka : 16,031 m2 } \\
\hline To & I Lahan & $29,254 \mathrm{~m} 2$ & \\
\hline
\end{tabular}

\section{- Pendekatann Aspek Arsitektural}

Bangunan Perpustakaan yang direncanakan adalah bangunan yang menerapkan unsur-unsur pendekatan Arsitektur Futuristik. Dalam pemikirannya, Arsitektur Futuristik mengarah atau meuju ke masa depan. Futuristik menggambarkan bahwa perencanaan dan pembangunannya tidak berdasarkan sesuatu yang terkait dengan masa lalu, akan tetapi mencoba untuk menggambarkan masa depan.

Karakter Arsitektur Futuristik didukung penuh dengan menggunakan bentuk dasar jajar genjang tersebut. Sedangkan bentuk lingkaran dan persegi diterapkan sebagai unsur pendukung tepatnya sebagai caffe dan took buku. Bentuk linkara dikombinasikan dengan jajar genjang dimana sebagai hirarki yang dapat melihat view Kawasan perpustakaan dengan difasilitasi tempat membaca buku.

Dalam perencanan gedung Perpustakaan Nasional ini menerapkan konsep Metafora .

\section{PEMBAHASAN}

Dalam perancangan arsitektur, analisi tapak merupaka tahap penilain evaluasi dari mulai kondisi fisik, kondisi non fisik hingga standar peraturan kebijakan kemudian menghasilkan analisisi eksternal dan internal yang meliputi komponen desain berupa problem, limitasi, potensi fisik dann fisik yang kemudian terbentuk konsep tapak pada suatu site.

Perancangan Perpustakaan Nasional memiliki lahanseluas 29,254 m2. Dengan Asumsi luas area terbangun 13, $223 \mathrm{~m} 2$ Area terbuka atau tidak terbangun 16,031 m2 yang dialokasikan sebagai ruang terbuka hijau pada bangunan Perpustakaan Nasional. 


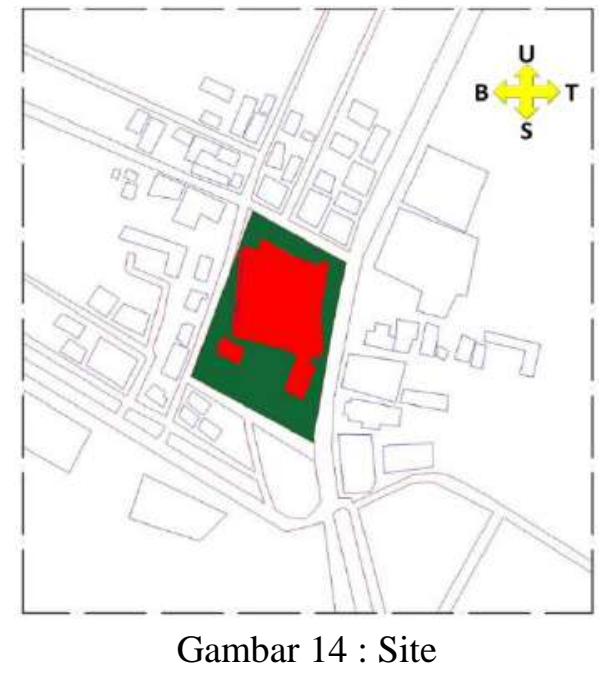

A. Konsep Terhadap Aksesbilitas

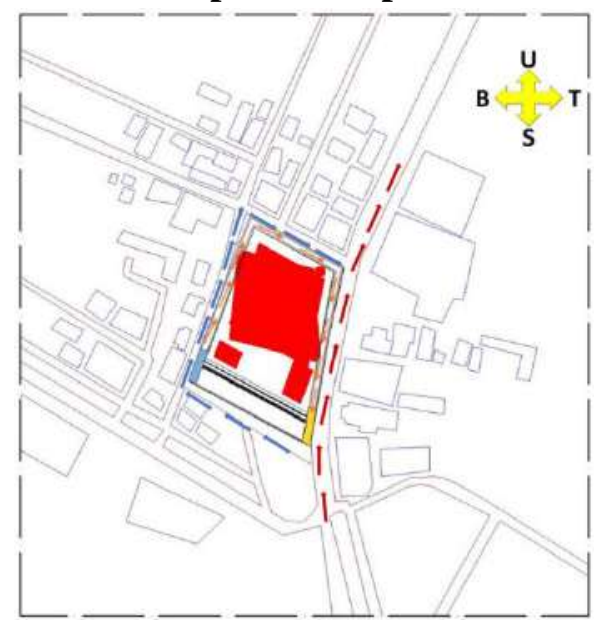

Gambar 15 : Konsep Terhadap Analisa Aksesbilitas

Keterangan :

Jalan dua arah

Jalan satu arah

$\longrightarrow$ Sirkulasi jalan pada area Perpustakaan Nasional

Pintu masuk

Pintu keluar

\section{B. Konsep terhadap Analisa Kebisingan}

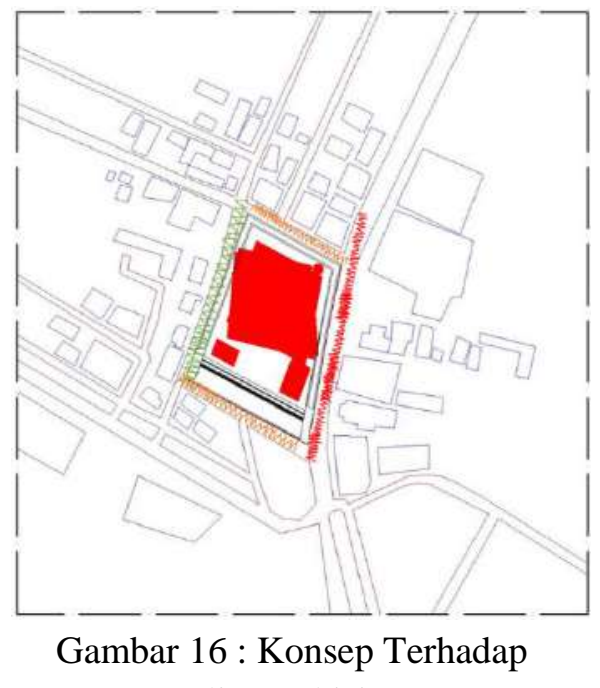

Analisa Kebisingan

Keterangan :

Tingkat Kebisingan Tinggi Ammumumum Tingkat Kebisingan Sedang Mmmmumumum Tingkat Kebisingan Rendah Ammumumum

C. Konsep Terhadap Analisa Matahari

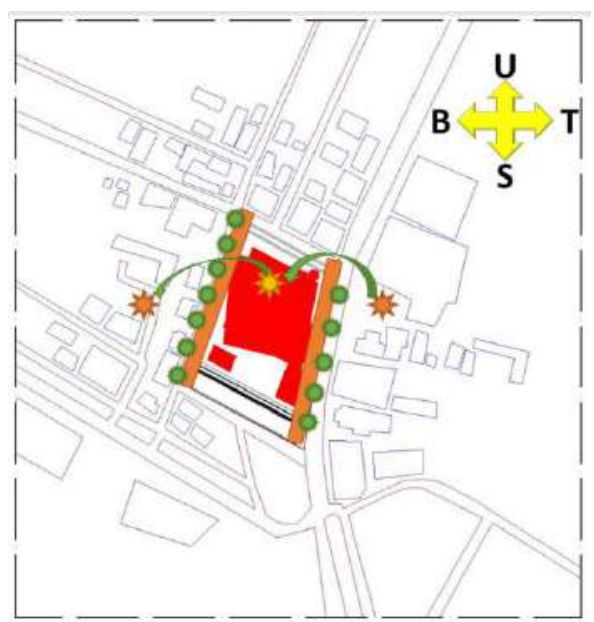

Gambar 17 : Konsep Terhadap Analisa Matahari

Keterangan :

Potensi Paling tinggi terpapar sinar matahari

Area terbangun 


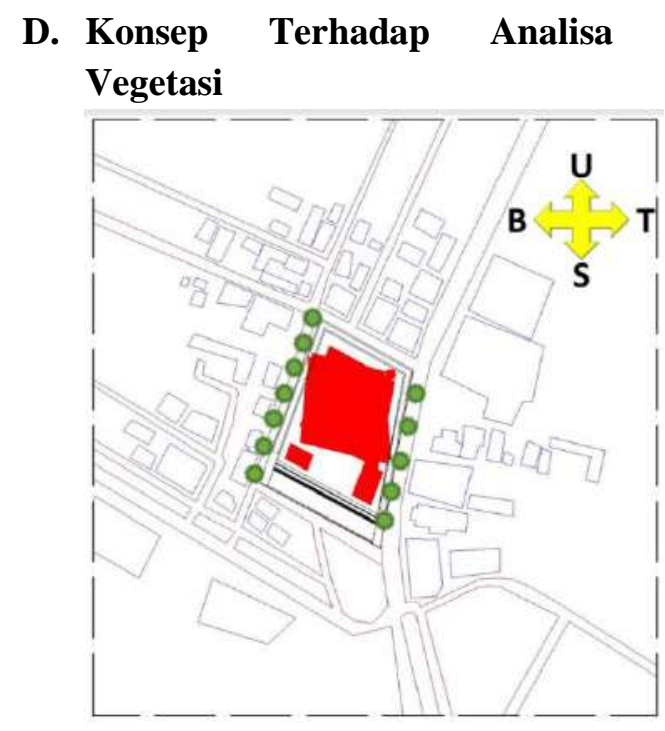

Gambar 18 : Konsep Terhadap Analisa Vegetasi

Keterangan :

Titik Vegetasi

\section{E. Konsep Terhadap Zoning}

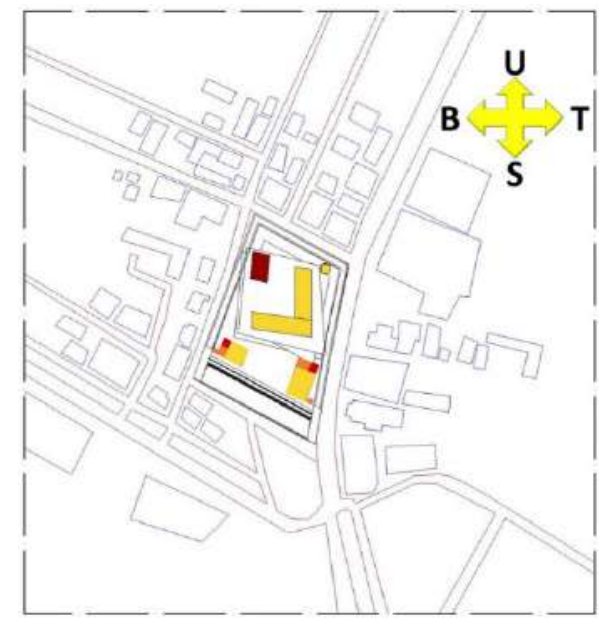

Gambar 19 : Zoning Horizontal

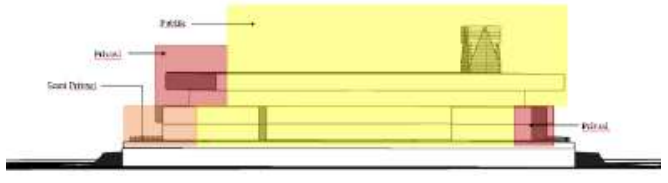

Gambar 20 : Zoning Vertikal

\section{F. Konsep Gubahan Massa}

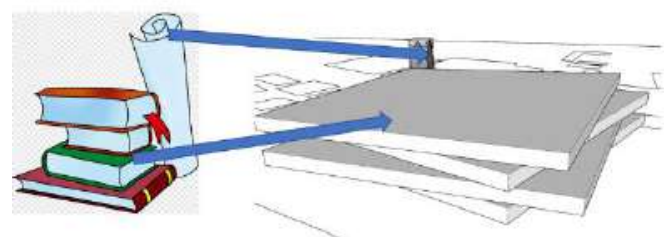

Gambar 21 : Gubahan Massa
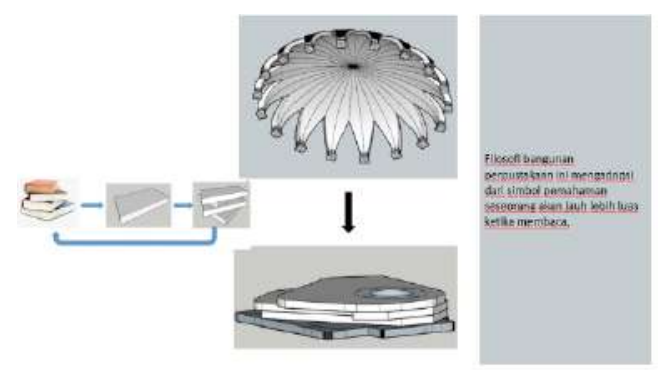

Gambar 22 : Gubahan Massa

Filosofi bangunan di amil dari sebuah tumbukan buku yang ditransformasikan dengan disempurnakan disetiap sudut menjadi setengah lingkaran, serta terdapat ornament di bagian atas bangunan yang memiliki filosofi dengan membaca seseorang bisa menjakau semua hal.

\section{A. Konsep Eksterior Bangunan}

Pada eksterior depan bangunan atau fasade dalam perencanaan Perpustakaan Nasional dengan Pendektaan Arsitektur Futuristik akan di dominasi oleh penggunaan kaca agar lebih terbukadengan 
Beberapa penjelasan sebagai berikut :

1. Penggunaan material dominan kaca transparan guna mendekati dengan konsep arsitektur futuristik yang lebih dominan material pre fabrikasi.

2. Pemilihan warna cat abu-abu dengan perpaduan putih dimaksud seperti warna plester dan warna dasar yang melambangkan futuristik.

3. Ukuran fasade yang berukuran besar dan berbentuk persegi.

4. Penggunaan vegetasi disektar bangunan guna meredam sinar matahari

5. Perawatan bangunan menjadi mudah

6. Mengurangi biaya pembangunan yang terlalu mahal.

\section{B. Konsep Interio Bangunan}

Pada Perencanaan Nasional akan menekankan pada pendekatan Arsitektur Futuuristik dimana penggunaan material dan furniture yang fungsional menjadi perhatian penting :

1. Penggunaan material laintai dari batu granit guna menambah pantulan sinar lampu.

2. Penggunaan pintu kaca geser pada konsep interior kantor yang berguna, serta di bagian ruang baca.

3. Memberikan material keadp suara pada beberapa ruangan yang membutuhkan seperti auditorium.

\section{Konsep Struktur}

\section{- Pondasi}

Standar daya dukung tanah menurut Peraturan Pembebanan Indonesia untuk Gedung tahun 1983 adalah :
a. Tanah keras (lebih dari $2-5 \mathrm{~kg} / \mathrm{cm} 2$ )
b. Tanah sedang $(2-55 \mathrm{~kg} / \mathrm{cm} 2)$
c. Tanah lunak $(0,5-2 \mathrm{~g} / \mathrm{cm} 2)$
d. Tanah amat lunak $(0+0,5 \mathrm{~kg} / \mathrm{cm} 2)$

Sistem pondasi bangunan yang dipilih berdasarkan jenis tanah dengan ketinggiam bangunan 4 lantai menggunakan pondasi Strauss Pile.

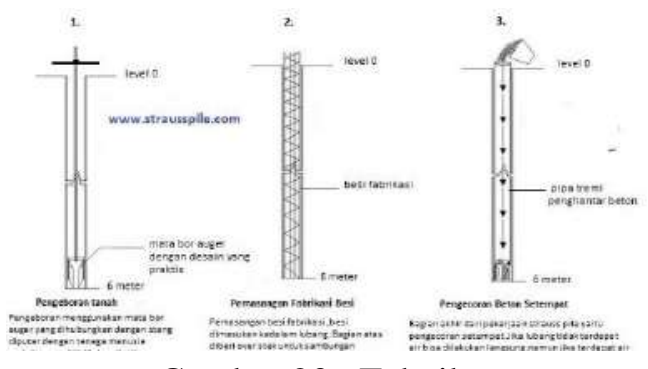

Gambar 23 : Teknik

Pemasangan Strauss Pile

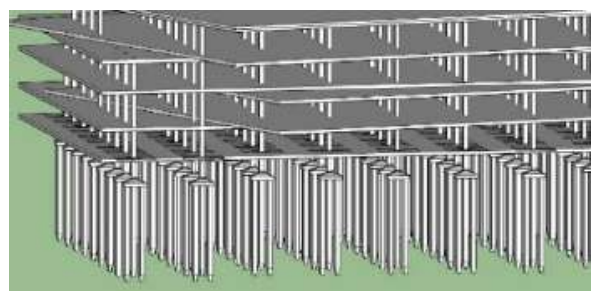

Gambar 24 : Konsep Struktur Pondasi

\section{Struktur Kolom dan Balok}

Kolom berfungsi sebagai penompang beban dari atap. Pada arsitektur high tech penggunaan kolom pada bangunan dapat menggunakan bahan dari baja yang bersilangan antara satu dan lainnya atau menggunakan bahan lain.

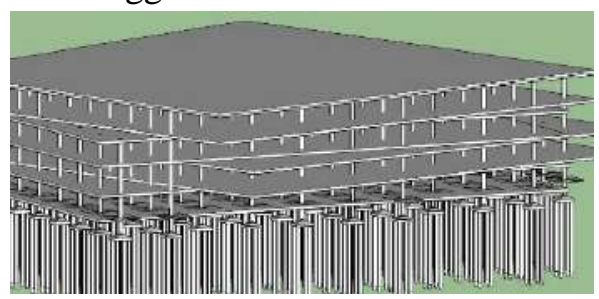

Gambar 25 : Konsep Kolom dan balok

\section{- Struktur Atap}




\section{Konstruksi Dak beton}

Konstruksi Dak beton adalah pembatas lantai termasuk juga bagian atap yang terbuat dari beton. Dak adalah istilah yang berarti pembatas antara lantai bawah dengan lantai yang di atasnya. Dak juga sering di tujukan sebagai konstruksi yang berada di bagian paling atas.

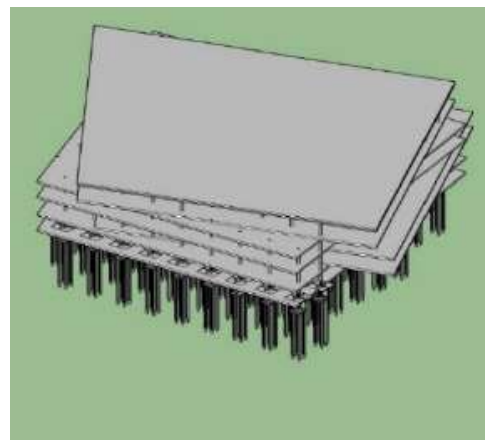

Gambar 26 : Konsep Atap

\section{Konsep Ruang}

Tabel 2 : Progam Ruang

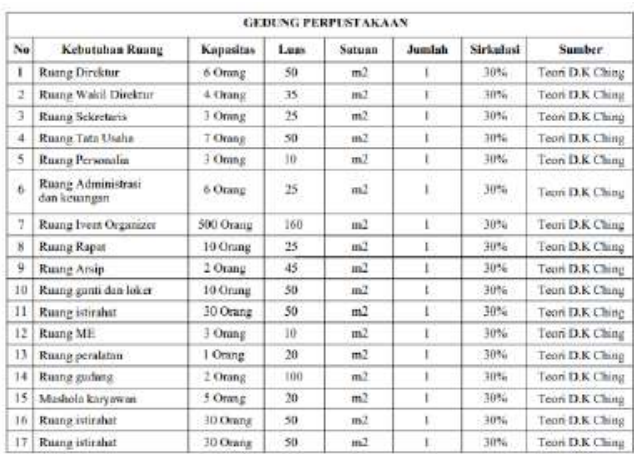

Tabel 3 : Progam Ruang

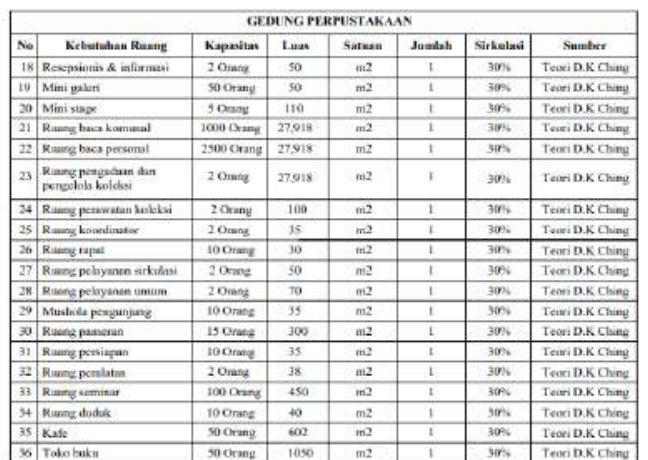

\section{KESIMPULAN}

Perpustakaan Nasional dengan Pendekatan Arsitektur Futuristik di Kalimantan Timur berlokasi di Jl. Bayangkara Samarinda, Kalimantan Timur dengan luas lahan 29,254 m2. Terdapat jaringan utilitas (lampu penerangan jalan/tiang listrik, air dan jalan selebar 4 meter dengan 2 jalur), Arus lalu lintas ramai, berada di Kawasan Pendidikan, meliputi Universitas, Sekolah menengah Atas, sekolah menengah pertama, Masjid, Kawasan Perumahan, dan Villa.

Timur : IKIP Samarinda

Barat : Universitas Mulawarman Selatan : Mall Lembuswana

Utara : Apartemen Pandan Wangi Suite Samarinda

Perencanaan dan Perancangan Perpustakaan Nasional dengan pendekatan Arsitektur futuristik ini, guna untuk melengkapi fasilistas yang belum tersedia di Kalimantan Timur, dimana Kalimantan Timur adalah menjadi Ibu kota baru Negara Indonesia di beberapa tahun kedepan.

Perpustakaan Nasional, di desain dengan pendekatan Arsitektur futuristik, Dimana perencanaan dan perancangan Perpustakaan ini menggunakan bentuk transformasi sebuah tumpukan sebuah buku yang di kombinasikan dengan bentuk setengah lingkaran yang diterapkan di beberapa sudut bangunan, untuk menciptkan sebuah lengkungan sebagai salah satu syarat pendekatan Arsitektur futuristik.

Berikut merupakan hasil dari desain Perpustakaan Nasional dengan pendekatan Arsitektur Futuristik 


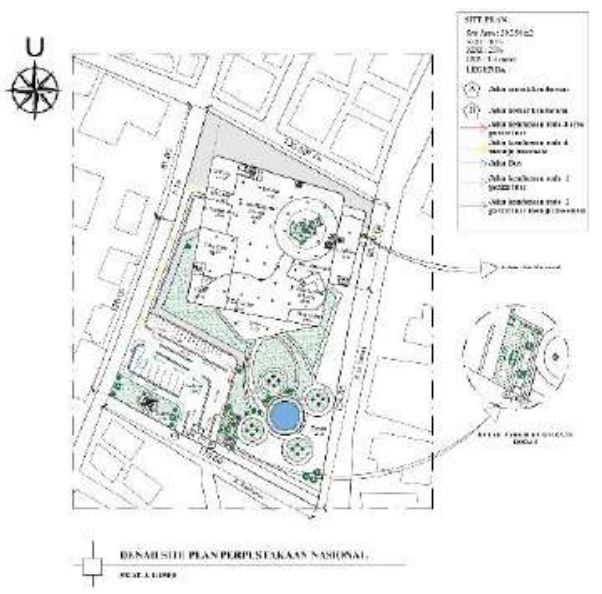

Gambar 27 : Sitplan

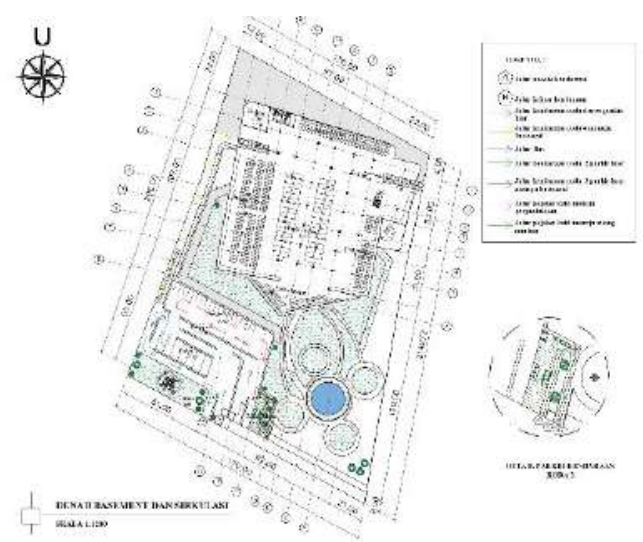

Gambar 28 : Denah Basement dan Sirkulasi

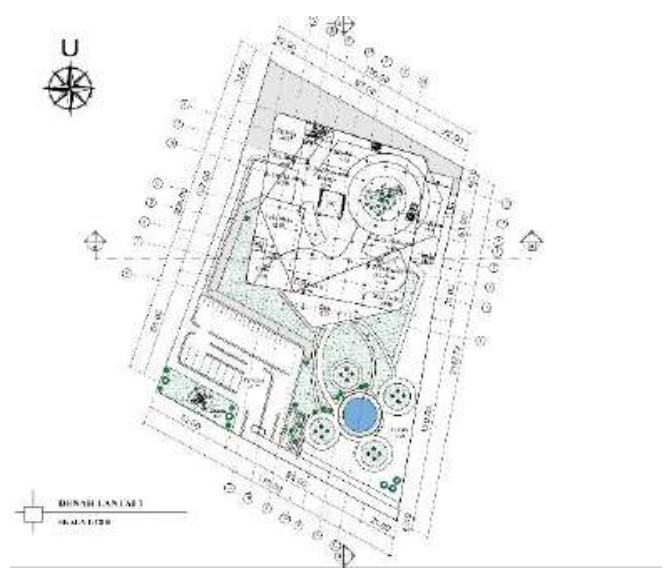

Gambar 29 : Denah Lantai 1

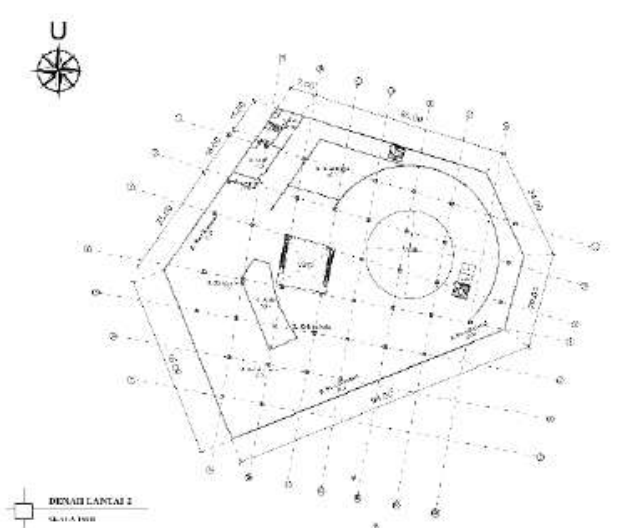

Gambar 30 : Denah Lantai 2

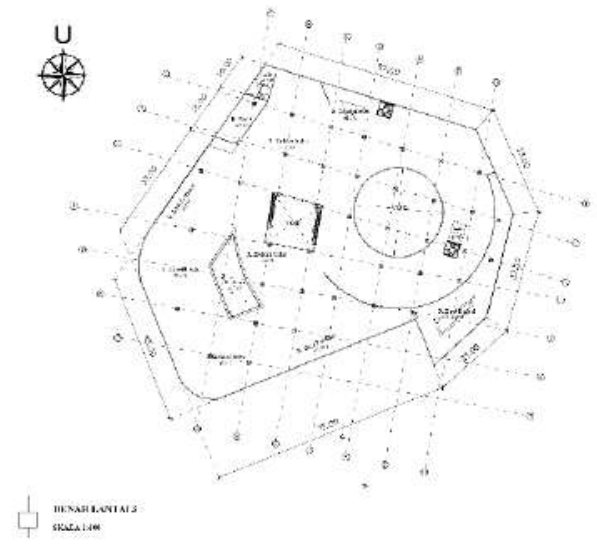

Gambar 31 : Denah Lantai 3

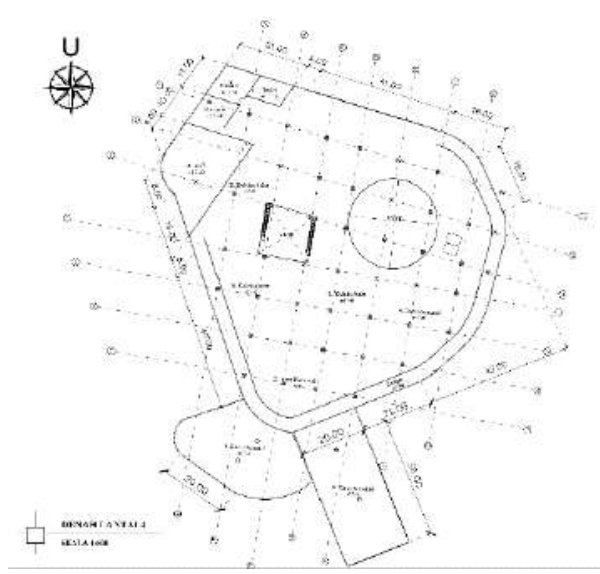

Gambar 32 : Denah Lantai 4 


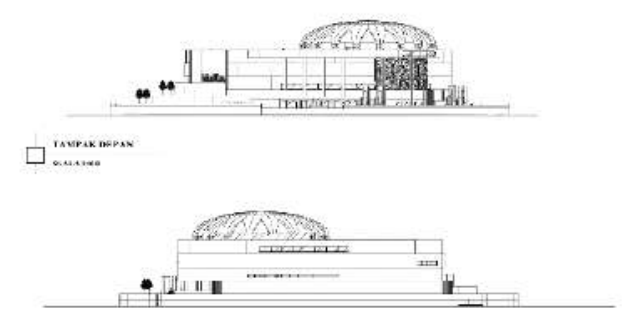

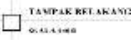

Gambar 33 : Tampak Depan \& Tampak Belakang

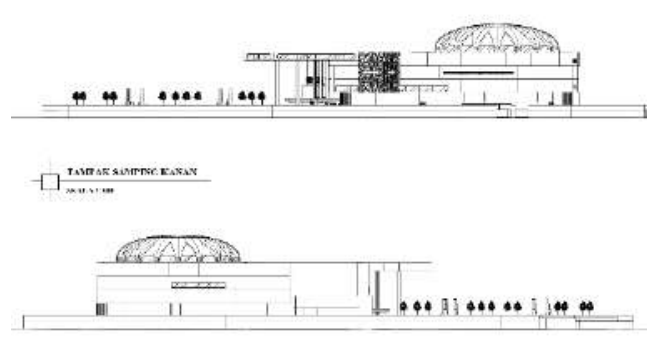

口

Gambar 34 : Tampak Kanan \& Tampak Kiri

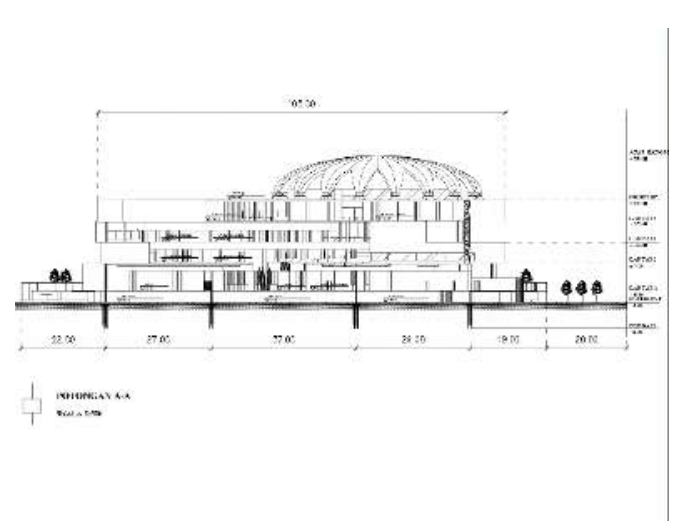

Gambar 35 : Potongan A-A

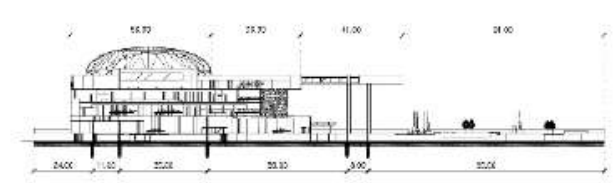

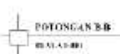

Gambar 36 : Potongan B-B

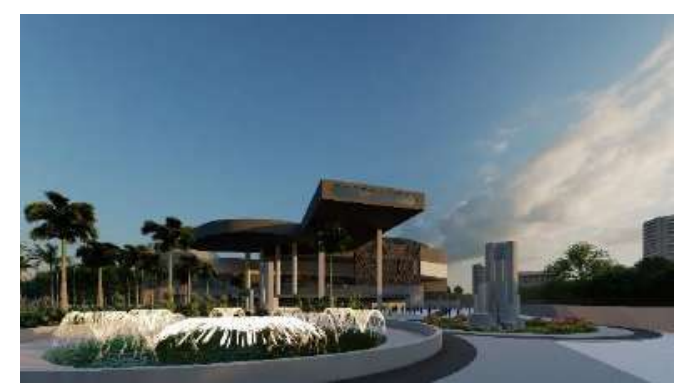

Gambar 37 : Visualisasi 3D Eksterior

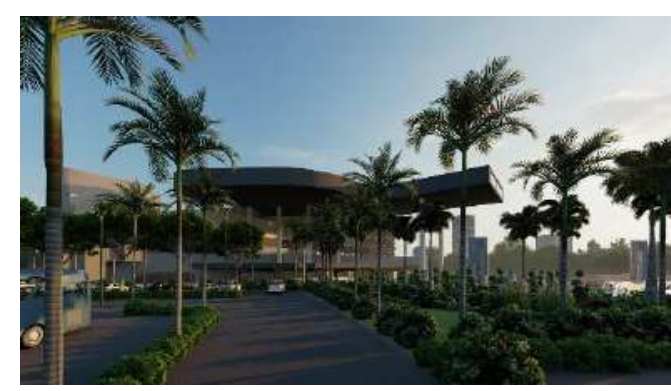

Gambar 38 : Visualisasi 3D Eksterior

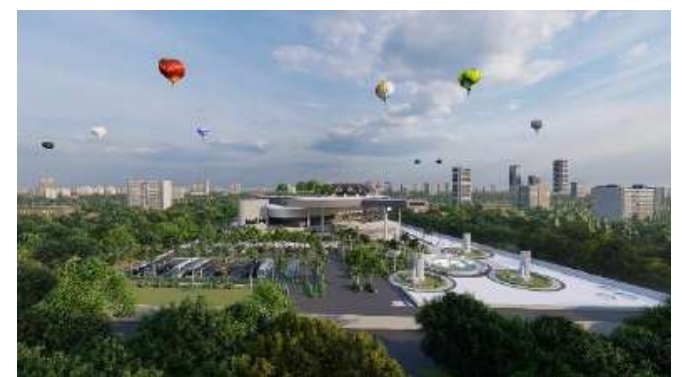

Gambar 39 : Visualisasi 3D Eksterior 


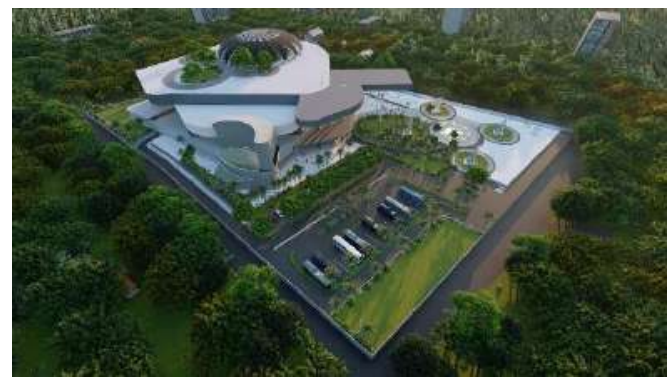

Gambar 40 : Visualisasi 3D Eksterior

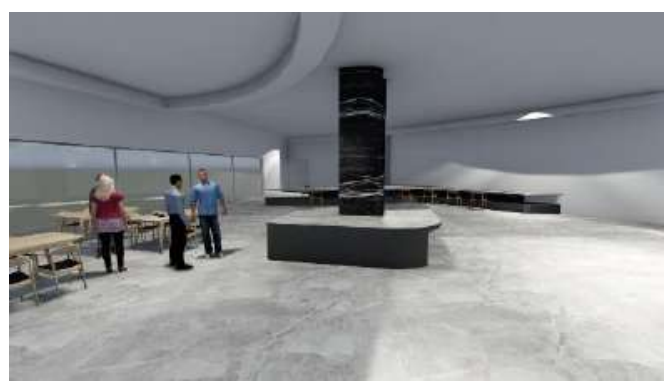

Gambar 41 : Visualisasi 3D Interior Caffe

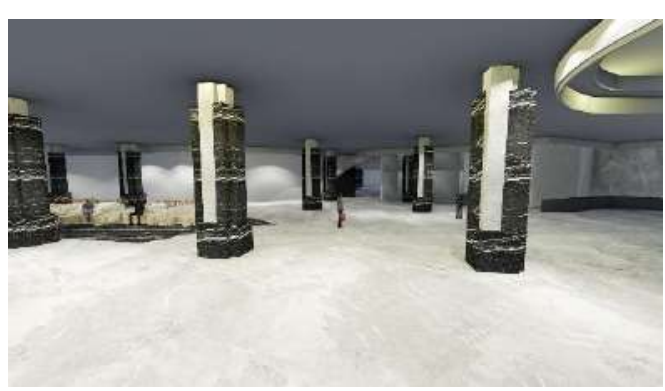

Gambar 42 : Visualisasi 3D Interior Lobby

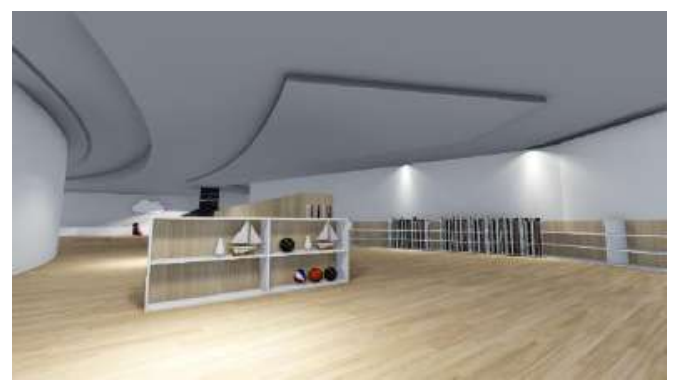

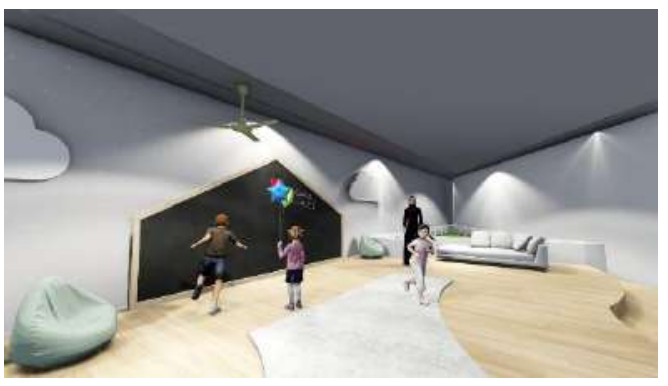

Gambar 43 : Visualisasi 3D Interior Perpustakaan Anak

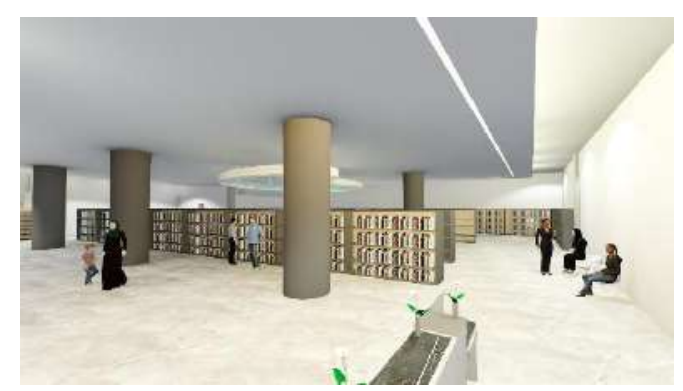

Gambar 44 : Visualisasi 3D Interior Toko Buku

\section{DAFTAR PUSTAKA}

Ernst Neufert, 1996 Data Arsitek ed. 33. Terjemhan: Dr. Ing Sunarto Tjahajadi. 289 Hal.

Ernst Neufert, 2002 Data Arsitek ed. 33. Terjemhan: Dr. Ing Sunarto Tjahajadi. Dr. Ferryanto Chaidir. 3 (Placeholder1)02 Hal.

Francis D.K. Ching, 2008 Arsitektur Bentuk, Ruang, dan Tatatanan ed. 3. Terjemahan : Dr. Hanggan Situmorang. 446 Hal.

Direktorat Penyelidikan Masalah bangunan, 1981 Peraturan Pembebanan Indonesesia untuk gedung. Yayasan Lembaga Penyelidikan Masalah Bangunan, Bandung. 
Encyclopedia of Information and Library Science (1997). Definsi perpustakaan nasional.

(Haines, 1950) dan (Chiara,1980) Kriteria Bangunan Futuristik.

(Tiffany, 2012) Definisi Futuristik. (Placeholder2)

https://www.archdaily.com/ (diakses 01 Semptember 2020)

https://fidansafira.wordpress.com/2014/1

0/02/jenis-jenis-perpustakaan/

(diakses 01 September 2020)

http://www.bpkp.go.id/pustakabpkp/inde x.php?p=wujud\%20perpus\%20idea 1 (diakses 15 Oktober 2020). 